\title{
Implementasi Nilai-Nilai Pancasila Bagi Generasi Muda di Era Globalisasi
}

\author{
Sabian Nuraprilia ${ }^{1 *}$, Dinie Anggraeni Dewi ${ }^{2}$ \\ 1,2 Universitas Pendidikan Indonesia, Indonesia \\ *e-mail: sabianuraprilia@upi.edu
}

\begin{abstract}
This research was conducted to find out, explore and examine more deeply the implementation of Pancasila values for the younger generation in the current era of globalization. This research study uses a qualitative method or a descriptive approach. The results of this discussion are obtained from the results of literature studies from various sources such as journals, books and articles. Then later results will be obtained regarding this implementation, which aims to find out whether the implementation of Pancasila values in the younger generation in this era of globalization is going well or even vice versa. From the results of this research, we can conclude that the implementation of Pancasila values in the younger generation has not been implemented properly, there are still many young people who are indifferent to these values, it is necessary to replant Pancasila values in the younger generation. In the implementation of Pancasila values in this era of globalization, it is hoped that all will take part in instilling the values of Pancasila. We as citizens should also be aware of the values of Pancasila. And don't let the values of Pancasila that have been formulated by our predecessors who have gone to great lengths to unite the Indonesian people be ignored, because they are blown away by the influence of an increasingly advanced era.
\end{abstract}

Keywords: Pancasila, Young Generation, Globalization

\begin{abstract}
Abstrak: Penelitian ini dilakukan untuk mengetahui, menelusuri dan menelaah lebih dalam mengenai implementasi nilai-nilai Pancasila bagi generasi muda di era globalisasi sekarang ini. Kajian penelitian ini menggunakan metode kualitatif atau pendekatan secara deskriptif. Hasil pembahasan ini diperoleh dari hasil studi kepustakaan dari berbagai sumber seperti jurnal, buku dan artikel. Kemudian nantinya akan diperoleh hasil tentang implementasi ini, yang bertujuan untuk mengetahui apakah implementasi nilai-nilai Pancasila pada generasi muda di era globalisasi ini berjalan baik atau bahkan sebaliknya. Dari hasil penelitian yang dilakukan ini dapat kita simpulkan bahwa implementasi nilai-nilai Pancasila di generasi muda itu belum terimplementasikan dengan baik, masih banyak generasi muda yang acuh terhadap nilai-nilai tersebut, maka perlu adanya penanaman kembali nilai-nilai Pancasila pada generasi muda. Pada implementasi nilai-nilai Pancasila di era globalisasi ini, diharapkan semua ikut andil dalam menanamkan nilai-nilai Pancasila. Kita sebagai warga negara juga yang seharusnya sudah sadar akan nilai-nilai Pancasila. Dan jangan sampai nilai-nilai Pancasila yang sudah dirumuskan oleh para pendahulu kita yang sudah bersusah payah mempersatukan bangsa Indonesia terabaikan begitu saja, karena terhempas oleh pengaruh zaman yang semakin maju.
\end{abstract}

Kata kunci: Pancasila, Generasi Muda, Globalisasi

Copyright (c) 2021 The Authors. This is an open access article under the CC BY-SA 4.0 license (https//creativecommons org/licenses/by-sa/4.0/)

\section{PENDAHULUAN}

Pancasila merupakan dasar sekaligus ideologi bangsa yang menegakkan prinsip-prinsip dalam kehidupan bernegara. Pancasila yang ada di dalam pembukaan UUD 1945 dan pasal-pasal yang telah diuraikan, mempunyai arti bahwa nilai-nilai yang terdapat dalam Pancasila menjadi nilai yang mengatur kehidupan berbangsa dan bernegara, baik dalam bidang pendidikan, hukum, 
politik, budaya, masyarakat dan masih banyak bidang yang lainnya. Nilai-nilai yang tercantum dalam Pancasila, antara lain terdapat nilai ketuhanan, kemanusiaan, persatuan, kerakyatan serta keadilan. Kelima nilai itu merupakan satu kesatuan yang utuh.

Dalam kehidupan kenegaraan, perwujudan nilai Pancasila harus nampak dalam peraturan perundangan yang berlaku, karena dengan nampaknya hal tersebut, dapat menuntun dan bersikap sesuai dengan peraturan yang sudah disesuaikan dengan Pancasila (Aminullah, 2018). Pembelajaran budaya serta kepribadian bangsa mempunyai tujuan yaitu untuk mempersiapkan masyarakat menjadi baik dan mempunyai kemauan untuk mengimplementasikan nilai-nilai Pancasila dalam kehidupannya selaku warga negara (Judiani, 2010).

Pancasila selaku sistem filsafat, mempunyai dasar ontologis, dasar epistemologis serta dasar aksiogis, yang mana dasar-dasar itu menjadi pembeda dengan sistem filsafat lain. Notonagoro menyatakan bahwa hakekat dasar ontologis Pancasila adalah manusia, sebab manusia merupakan subjek hukum pokok dari Pancasila (Dani, 2012). Pancasila selaku filsafat bangsa sudah dipilih melalui perenungan yang dalam oleh the founding fathers bangsa Indonesia. Oleh karena itu, kepercayaan terhadap Pancasila ialah pangkal kebenaran buat dapat memahami eksistensi bangsa Wahidin, S. (Mayasari et al., 2021).

Dalam Pancasila juga terkandung beberapa nilai, antara lain, nilai material, nilai vital, nilai kebenaran, nilai keindahan, nilai kebaikan ataupun nilai kesucian. Darmodiharjo dan Sidarta menyatakan dalam tulisan Hadiwijono, bahwa Pancasila itu memiliki nilai secara harmonis dan sistematis, yang diawali dari sila pertama, yaitu Ketuhanan Yang Maha Esa sebagai dasar, sampai dengan sila ke lima, yaitu Keadilan Sosial Bagi Seluruh Rakyat Indonesia sebagai tujuan (Hadiwijono, 2016).

Dalam era digital, bangsa Indonesia harus mulai melakukan berbagai terobosan baru dalam segala bidang. Sebagai generasi muda Bangsa Indonesia harus mampu memanfaatkan era digital ini dengan semaksimal mungkin, sehingga tidak ada lagi generasi muda yang terprovokasi oleh arus dari luar (Nur, 2020). Generasi muda merupakan generasi yang memiliki kemampuan, semangat tinggi dan memiliki wawasan yang lebih luas untuk mengembangkan dan memajukan negara. Untuk mencapai sebuah revolusi bagi suatu bangsa, butuh generasi muda 
yang mampu mengubah Bangsa Indoesia untuk lebih maju, namun harus tetap berpegang pada dasar Negara, yaitu Pancasila dan nilai-nilai yang terkandung didalamnya (Febrianti, 2019). Generasi muda yang baik adalah pemuda yang tumbuh dan berkembang menjadi seorang pribadi yang unggul dan mandiri dalam melaksanakan tugasnya (Febrianti, 2019)

Pada era saat ini banyak generasi muda yang moralnya sudah rusak karena beberapa hal yang mempengaruhi mereka. Diantaranya seperti dampak buruk dari globalisasi, salah pergaulan, pengaruh digital yang semakin canggih, narkoba, serta masih banyak lagi hal-hal negatif yang mempengaruhi moral generasi muda. Jika dilihat dari kasus tersebut, sangat memperihatinkan dan butuh atensi yang lebih khusus untuk generasi muda.

Tantangan yang dihadapi oleh Negara saat ini adalah adanya perbedaan berbagai paham yang kurang sesuai dengan nilai-nilai ideologi Pancasila. Kondisi seperti ini akan menjadikan adanya dialektik di dalam diri warga negara. Perihal tersebut dipengaruhi oleh kurangnya pemahaman dan kesadaran akan nilai-nilai Pancasila, serta dapat dipengaruhi oleh keadaan daerah. Keadaan daerah ini meliputi pola fikir, sikap, perilaku yang kurang baik dengan nilai-nilai Pancasila (Silitonga et al., 2020). Untuk itu, butuh adanya perubahan-perubahan supaya generasi penerus nantinya mempunyai akhlak serta moral yang lebih baik dengan cara mengamalkan nilai-nilai Pancasila sebagai pedoman hidup bangsa.

\section{METODE}

Penelitian ini menggunakan metode jenis studi literatur. Penelitian ini berisi tentang implementasi nilai-nilai Pancasila bagi generasi muda di era globalisasi dengan menelusuri sumber-sumber pustaka sehingga ditemukan tentang gambaran bagaimana penerapan nilai-nilai Pancasila pada generasi muda sekarang ini. Metode penelitian ini juga menggunakan metodologi deskriptif melalui pendekatan kualitatif.

\section{HASIL DAN PEMBAHASAN}

Muttaqin (2019) melakukan penelitian tentang implementasi nilai-nilai Pancasila dikalangan generasi muda di Desa Sumi Kecamatan Lambu, Kabupaten Bima. Berdasarkan hasil observasinya, bahwa implementasi nilai-nilai Pancasila di daerah tersebut harus mencerminkan realitas yang hidup serta berkembang dalam 
permasyarakatan. Artinya mampu dijabarkan dalam berbagai aspek di kehidupan nyata. Selanjurnya dalam penelitian Anggraini et al. (2020), dalam pengamatannya di berbagai daerah, seperti di lingkungan kampus Unisma, organisasi di Kota Batu atau mahasiswa di sekitaran Dinoyo Malang terlihat bahwa masyarakat dan mahasiswa sudah tidak menerapkan nilai-nilai Pancasila yang dibuktikan dari; 1) pada saat adzan berkumandang, masih banyak masyarakat maupun mahasiswa yang masih tetap nongkrong, 2) Saat berkumpul, masih banyak orang yang memperlihatkan sikap individualnya, 3) Masih banyak sikap pilih kasih dalam bermasyarakat, saling berkelompok dalam berteman, rasa gotong royong yang semakin memudar, dan lain sebagainya.

Dari beberapa hasil peneletian diatas, dapat kita simpulkan bahwa implementasi nilai-nilai Pancasila di generasi muda belum terimplementasikan dengan baik, masih banyak generasi muda yang acuh terhadap nilai-nilai tersebut, maka perlu adanya penanaman kembali nilai-nilai Pancasila pada generasi muda.

\section{Pancasila sebagai Dasar Negara}

Pancasila sebagai dasar negara memiliki arti bahwa nilai-nilai yang tercantum dalam Pancasila wajib menjadi pedoman ataupun landasan dalam membentuk serta menyelenggarakan negara. Menurut Muzayin (dalam Octavian, 2018) adanya Pancasila, perpecahan bangsa akan lebih mudah dihindari sebab pemikiran Pancasila ini juga bertumpu pada pola hidup yang pada atas keseimbangan, keselarasan, dan keserasian, sehingga berbagai perbandingan dapat dibina menjadi pola kehidupan yang bermacam-macam dalam satu keseragaman yang kuat.

Pancasila juga memberikan arahan tentang hukum yang lebih baik lagi dengan berlandaskan pada nilai-nilai ketuhanan, kemanusiaan, persatuan, kerakyatan serta keadilan. Dengan adanya peraturan yang berlandaskan pada pada nilai-nilai tersebut, maka diharapkan bahwa warga negara bisa memahami serta melakukan nilai-nilai tersebut dalam kehidupan sehari-hari.

\section{Makna Pancasila sebagai Ideologi}


Makna Pancasila sebagai ideologi adalah cita-cita yang ingin dicapai suatu bangsa. Ideologi menurut Ubaidillah (dalam Asmaroini, 2016) mempunyai peranan yang sangat penting dalam proses memelihara integritas nasional, terutama di negara berkembang, seperti Indonesia sendiri. Ideologi negara dan ideologi bangsa dapat dikatakan sebagai suatu pemikiran yang sangat mendalam, serta diyakini kebenarannya oleh sesuatu bangsa buat mempersatukan gerak langkah suatu kelompok, kalangan serta partai buat mempereatukan diri guna dalam kehidupan politik.

Tujuan politik sesuatu negara dalam mewujudkan tujuan nasional bersumber pada kepentingan nasional negara. Pancasila pada hakikatnya bukan hanya sekedar hasil perenungan saja, tetapi Pancasila diangkat atas nilai-nilai adat istiadat, nilai-nilai kebudayaan, dan nilai religius yang ada dalam pamikiran hidup masyarakat Indonesia. Semboyan 'Bhineka Tunggal Ika' dalam Pancasila diterapkan untuk warga Indonesia dalam kesatuan yang utuh, yaitu Negara Kesatuan Republik Indonesia. Sebab Pancasila sebagai suatu pandangan hidup Nasional yang menanggulangi faham perseorangan, kalangan, suku bangsa serta agama.

Pancasila sebagai ideologi nasional menempatkan segala kepentingan bangsa serta negara dalam peran yang paling utama diatas kepentingan yang lainnya. Dengan demikian, Pancasila selaku pandangan hidup bangsa ialah totalitas pemikiran, cita-cita, keyakinan serta nilai-nilai bangsa yang harus diimplementasikan dalam kehidupan bermasyarakat, berbangsa serta bernegara.

\section{Nilai-nilai yang Terkandung dalam Pancasila}

Menurut Kaelan dan Zubaidi (dalam Asmaroini, 2016), sebagai suatu dasar filsafat negara maka sila-sila Pancasila merupakan suatu sistem nilai. Pancasila memiliki serangkaian nilai, yaitu ketuhanan, kemanusiaan, persatuan, kerakyatan, dan keadilan. Nilai-nilai dasar Pancasila seperti ketuhanan, kemanusiaan, persatuan, kerakyatan, dan keadilan yang bersifat universal, objektif, artinya nilainilai tersebut dapat dipakai dan diakui oleh negara-negara lain. Pancasila bersifat subjektif, artinya bahwa nilai-nilai Pancasila itu melekat pada pembawa dan pendukung nilai Pancasila itu sendiri, yaitu masyarakat, bangsa, dan negara Indonesia. 


\section{Sila Pertama Ketuhanan Yang Maha Esa (Nilai Ketuhanan)}

Pada sila pertama ini, bahwasanya Bangsa Indonesia itu adalah Negara yang monotheisme, yaitu percaya akan adanya Tuhan yang satu. Atau bisa disebut juga, bahwa negara Indonesia itu berlandaskan agama.

Pancasila pada sila pertama ini, merupakan sebuah falsafah yang sesuai dengan agama. Beragam agama sudah semestinya tidak bersifat hierarkis, tetapi harus bersikap egaliter, dan menjunjung tinggi rasa toleransi antar umat beragama. Oleh karena itu, sebagai umat beragama yang beriman kepada Allah, sudah seharusnya kita menanamkan nilai kebenaran, kebaikan, kejujuran sehingga bisa menaikan moral Bangsa.

- Menurut Sari, L. K., dan Dewi (2021) nilai-nilai bangsa Indonesia yang tercermin dalam sila ini tercantum didalamnya prinsip asasi, yaitu;

1) Kepercayaan serta ketaqwaan kepada Tuhan Yang Maha Esa.

2) Kebebasan berat dan menganut agama yang dipercayainya, sebagai hak yang paling asasi bagi manusia.

3) Perilaku saling toleransi antar umat beragama.

4) Tidak memaksakan suatu agama ataupun keyakinan kepada orang lain.

\section{Sila Kedua Kemanusiaan yang Adil dan Beradab}

Dalam sila ini negara harus menjunjung tinggi nilai-nilai harkat serta martabat manusia sebagai makhluk yang beradab. Sila kedua dalam Pancasila ini mengandung suatu nilai kesadaran terhadap moral dan tingkah laku manusia yang didasarkan pada norma-norma dan kebudayaan, baik terhadap diri sendiri, terhadap sesama manusia maupun terhadap lingkungan.

- Pada sila ini terkandung didalamnya prinsip asasi, yaitu;

1) Mempunyai rasa kecintaan terhadap sesama manusia sesuai dengan prinsip kemanusiaan yaitu satu adanya.

2) Kejujuran.

3) Kesamaderajatan manusia.

4) Keadilan.

5) Keadaan.

\section{Sila Ketiga Persatuan Indonesia}


Manusia pada dasarnya sebagai makhluk individu dan makhluk sosial. Untuk itu, manusia memiliki perbedaan. Perbedaan itu diantaranya ada perbedaan suku, ras, golongan, maupun agama. Jika dilihat dari perbedaan yang sangat beragam, maka negara kita mengkaitkan diri dalam suatu kesatuan yaitu dalam semboyan 'Bhinneka Tunggal Ika'.

- Pada sila ini terkandung didalamnya prinsip asasi, yaitu;

1) Persatuan.

2) Rasa kebersamaan.

3) Rasa cinta terhadap tanah air.

4) Rasa cinta terhadap bangsa.

5) Bhineka Tunggal Ika.

\section{Sila Keempat Kerakyatan yang Dipimpin Oleh Hikmah Kebijakan dalam Permusyawaratan/Perwakilan}

Menurut Kaelan dan Zubaidi (dalam Asmaroini, 2016) menyatakan bahwa rakyat merupakan subjek pendukung negara. Negara merupakan dari rakyat, oleh rakyat dan untuk rakyat. Sehingga rakyat merupakan asal mula kekuasaan negara. Dalam sila ini terkandung nilai demokrasi dalam kehidupan negara.

- Dalam sila ini terkandung didalamnya prinsip asasi, yaitu;

1) Kerakyatan.

2) Musyawarah mufakat.

3) Demokrasi.

\section{Sila Kelima Keadilan Sosial Bagi Seluruh Rakyat Indonesia}

Pada sila ini, harus memiliki sikap adil di lingkungan masyarakat dan harus seimbang, tidak berat sebelah. Maksudnya adalah berusaha menjalankan hak dan kewajiban sebagai warga Negara Indonesia yang memiliki rasa tanggung jawab untuk ikut berperan mencapai cita-cita negara bersama tanpa meninggalkan nilainilai Pancasila sebagai dasar dan ideologi negara. Dalam keadilan wajib didasari oleh hakikat keadilan kemanusiaan yaitu; keadilan dalam ikatan manusia dengan dirinya sendiri, manusia dengan manusia lain, manusia dengan warga, serta ikatan manusia dengan Tuhannya.

Adapula konsekuensi nilai keadilan yang wajib terwujud, yaitu: 
1) Ikatan keadilan antara warga Negara terhadap warga negaranya sendiri.

2) Keadilan antara masyarakat Negara terhadap Negara nya.

3) Keadilan antara masyarakat Negara yang satu dengan masyarakat Negara yang lainnya.

- Didalamnya terkandung prinsip asasi, yaitu;

1) Keadilan.

2) Keadilan sosial.

3) Kekeluargaan.

4) Gotong royong.

\section{Tantangan Pancasila Sebagai Ideologi Negara di Era Globalisasi}

Globalisasi akan membawa pengaruh yang dapat dirasakan secara langsung terhadap perubahan di berbagai negara. Ada beberapa dampak dari perubahan itu yang berakibat memudarnya nasionalisme bangsa Indonesia. Maka dari itu Bangsa Indonesia harus meningkatkan nilai nasional dan ketahanan ideologi Bangsa Indonesia. Kemampuan dalam menghadapi berbagai tantangan yang melanda kehidupan nasional, sosial, dan politik bahkan mental suatu bangsa, harus dibentengi oleh dasar negara yaitu Pancasila.

Menurut Untari (dalam Asmaroini, 2016), Pancasila merupakan pedoman, sumber motivasi dan inspirasi, sekaligus sebagai standar pembenaran. Dengan demikian, pola aktivitas, perilaku, maupun hasil perilaku bangsa Indonesia harus sesuai dan tercermin pada Pancasila. Sehingga nantinya mampu meminimalisir dampak dari globalisasi yang pada nantinya membawa perubahan pada tatanan dunia, khususnya pada peserta didik.

Tantangan Pancasila pada masa globalisasi sekarang ini dapat mengecam eksistensi karakter bangsa. Dan Bangsa Indonesia terletak dalam pusaran arus globalisasi dunia. Meskipun hidup diantara pergaulan arus dunia, hal tersebut tidak menjadi penghalang Bangsa Indonesia untuk kehilangan jati dirinya.

\section{Implementasi Nilai-nilai Pancasila bagi Generasi Muda di Era Globalisasi}

Globalisasi tidak bisa dihindari oleh setiap masyarakat, khususnya pada masyarakat Indonesia. Maka diperlukan penumbuhan kembali terhadap nilai Pancasila bagi generasi muda yang dapat dimulai dari Pendidikan Sekolah Dasar hingga Sekolah Menengah Atas, bahkan sampai ke Perguruan Tinggi. 
Implementasi pada nilai-nilai Pancasila di era globalisasi ini bisa diterapkan mulai dari menumbuhkan sifat nasionalisme. Sifat nasionalisme ini bisa digali pada saat ada momentum penting negara, seperti peringatan sumpah pemuda, hari kemerdekaan, hari pahlawan, dan hari besar nasional lainnya.

Menumbuhkan semangat nasionalisme yang tangguh, misalnya semangat mengukir prestasi, belajar dengan sangat sungguh-sungguh demi nama baik bangsa dan negara, cinta serta bangga menggunakan produk dalam negeri, dan menanamkan nilai-nilai Pancasila dengan sebaik-baiknya.

\section{Pengamalan Nilai-nilai Pancasila}

Menerapkan nilai-nilai Pancasila dalam kehidupan sehari-hari, merupakan salah satu kedudukan bahwa Pancasila sebagai pandangan hidup berbangsa. Bangsa Indonesia harus bisa menghayati dan mengamalkan nilai-nilai kebenarannya. Jika tidak bisa mengamalkannya, bisa jadi Indonesia akan mudah dimanfaatkan oleh pihak-pihak tertentu sehingga terjadi perpecahan.

Menurut Rajasa (dalam Anggraini et al., 2020) bahwa generasi muda harus mengembangkan karakter nasionalisme melalui 3 proses, yaitu;

1) Sebagai pembangun karakter, artinya bahwa generasi muda harus membangun karakter yang positif dan mempunyai kemauan yang keras untuk menjunjung nilai-nilai Pancasila dan mengaktualisasikannya pada kehidupan.

2) Pemberdayaan karakter, artinya bahwa generasi muda harus menjadi role model karakter bangsa yang positif.

3) Perekayasa kepribadian, maksudnya kedudukan generasi muda sangat penting dalam ilmu pengetahuan serta kebudayaan, dan ikut serta dalam proses pengembangan kepribadian sesuai dengan pertumbuhan era.

Maka dari itu, sila-sila yang terdapat dalam Pancasila bisa diterapkan dengan cara:

1) Memiliki satu agama yang diyakininya, serta tidak pernah memaksa seseorang untuk masuk dan memeluk agama sesuai perintah kita. Karena setiap orang memiliki hak untuk memilih agama sesuai dengan yang dipercayainya.

2) Bisa menghargai perbedaan diantara berbagai macam suku, agama, ras, budaya serta bisa menjaga adab dan kesopanan di dalam berbagai kondisi.

3) Cinta pada tanah air, untuk menjaga kesatuan dan persatuan bangsa. 
4) Mengawasi dan memberikan saran terhadap penyelenggara kedaulatan rakyat, dan selalu mengutamakan keputusan dengan cara musyawarah mufakat untuk kepentingan bersama.

5) Sebagai Bangsa Indonesia senantiasa memberikan bantuan kepada orang yang mengalami kesusahan, bisa menghormati hasil musyawarah meskipun hasil musyawarah tersebut tidak sesuai, dan harus berani memperjuangkan keadilan untuk bersama.

Nilai-nilai yang terkandung dalam Pancasila dari dulu tidak pernah berubah, tetapi pada zaman sekarang penerapan nilai Pancasila yang sudah mulai luntur yang diakibatkan oleh pengaruh kemajuan IPTEK dan arus globalisasi.

\section{Dampak tidak adanya Penerapan Nilai Pancasila}

Sudah seharusnya generasi muda Bangsa Indonesia merasa bangga dengan Pancasila, karena Pancasila itu sendiri merupakan ideologi yang komplit. Karena dengan adanya Pancasila yang jauh lebih komplit itu mampu untuk mengubah Indonesia menjadi lebih baik lagi. Pancasila masih 'jauh bara dari api'. Karena yang terjadi pada saat ini bukanlah penerapan tentang nilai Pancasila, melainkan pergeseran Pancasila. Ketuhanan saja yang menjadikan pilar utama moralitas suatu bangsa telah diganti dengan keuangan. Permusyawarahan sebagai sikap kekeluargaan telah berubah menjadi kebrutalan. Selain itu juga, keadilan sosial berubah menjadi keserakahan.

Pergeseran makna Pancasila itu sendiri selain dari pihak masyarakat, tetapi tetap dilakukan juga oleh para penguasa. Pada masa-masa tertentu juga, Pancasila sudah dijadikan sebagai alat politik untuk para penguasa yang tetap ingin mempertahankan kekuasaannya. Tindakan tersebut yang dilakukan terhadap Pancasila ini turut sangat merubah eksistensi nilai dari Pancasila itu sendiri. Pancasila seakan-akan menjadi menakutkan, sehingga oleh sebagian masyarakat dijadikan sebuah simbol kekuasaan dan pertahanan salah satu pihak.

Dalam Pancasila juga masih dipengaruhi oleh beberapa faktor kondisional. Padahal, gugatan terhadap Pancasila sebagai dasar negara dengan sendirinya akan menjadi gugatan terhadap esensi dan eksistensi sebagai manusia dan warga negara Indonesia. Maka untuk menghadapi kedua ekstrim tersebut diperlukannya usaha bersama guna menghayati nilai-nilai Pancasila sebagai salah satu warisan budaya 
Bangsa Indonesia yang bernilai luhur. Pancasila yang merupakan suatu sistem filsafat yang tidak bertentangan dengan nilai-nilai agama, bersifat normatif dan ideal, sehingga dalam menjalankan pengamalannya merupakan tuntutan batin dan nalar bagi setiap warga dan Bangsa Indonesia.

\section{KESIMPULAN}

Pancasila merupakan pandangan hidup suatu bangsa, sebagai dasar negara, dan sebagai ideologi Nasional. Pancasila juga memberikan arahan tentang hukum yang berlandaskan pada nilai-nilai ketuhanan, kemanusiaan, persatuan, kerakyatan dan keadilan. Nilai-nilai tersebut bersifat universal, artinya nilai-nilai tersebut bisa diakui oleh negara lain.

Pancasila sebagai filsafat bangsa telah dipilih melalui perenungan yang dalam oleh the founding fathers bangsa Indonesia. Oleh karena itu, keyakinan terhadap Pancasila merupakan akar kebenaran untuk bisa memahami eksistensi bangsa. Pancasila pada hakikatnya bukan sekedar hasil perenungan saja, tetapi Pancasila diangkat atas nilai-nilai adat istiadat, nilai-nilai kebudayaan, serta nilai religius yang terdapat dalam pandangan hidup masyarakat Indonesia.

Implementasi pada nilai-nilai Pancasila di era globalisasi bagi generasi muda bisa diterapkan mulai dari menumbuhkan sifat nasionalisme. Sifat nasionalisme ini bisa digali pada saat ada momentum penting Negara Indonesia, seperti pada peringatan sumpah pemuda, hari kemerdekaan, hari pahlawan, dan hari besar nasional lainnya. Implementasi nilai-nilai Pancasila juga sebisa mungkin harus tetap diterapkan di kehidupan sehari-hari, jangan sampai generasi muda acuh terhadap nilai-nilai Pancasila.

Menumbuhkan semangat nasionalisme yang tangguh, misalnya semangat mengukir prestasi, belajar dengan sangat sungguh-sungguh demi nama baik bangsa dan negara, cinta serta bangga menggunakan produk dalam negeri, dan menanamkan nilai-nilai Pancasila dengan sebaik-baiknya.

\section{DAFTAR PUSTAKA}

Aminullah. (2018). Inplementasi Nilai-Nilai Pancasila Dalam Kehidupan Bermasyarakat. Jurnal Ilmiah IKIP Mataram, 3(1), 620-628.

Anggraini, D., Fathari, F., Anggara, J. W., Devon, M., \& Al, A. (2020).

Pengamalan nilai-nilai Pancasila bagi generasi milenial. 2(1), 11-18. 
457 | Jurnal Pendidikan dan Kewirausahaan Vol. 9 No. 22021

Asmaroini, A. P. (2016). Implementasi nilai-nilai Pancasila bagi siswa di era globalisasi. 4(2), 440-450.

Dani, P. (2012). Falsafah Pancasila Sebagai Norma Dasar (Grundnorm) Dalam Rangka Pengembangan Sistem Hukum Nasional. 1945(3), 1-10.

Febrianti. (2019). Upaya Pemuda Karang Taruna Gunung Tugel Community (Gtc) Dalam Membentuk Masyarakat Religius Melalui Kajian Keislaman Di Dusun Krajan Desa Baosan Lor Ponorogo (Doctoral dissertation, Universitas Muhammadiyah Ponorogo). 8-25.

Hadiwijono, A. (2016). Pendidikan Pancasila, eksistensinya bagi mahasiswa. 7(1), 82-97.

Judiani, S. (2010). Implementasi pendidikan karakter di sekolah dasar melalui penguatan pelaksanaan kurikulum. Jurnal pendidikan dan kebudayaan. 16(9).

Mayasari, A., Marmoah, S., \& Murwaningsih, T. (2021). Internalization Of Pancasila Values Based On Local Wisdom “Jaranan Turangga Yaksa” In Elementary School Atika Mayasari 1, Sri Marmoah 2, Tri Murwaningsih 3. 9(1), 80-95.

Muttaqin, Z. (2019). Pemahaman dan Implementasi Ideologi Pancasila di Kalangan Generasi Muda. 7(2).

Nur, K. (2020). Implementasi Nilai-Nilai Pancasila Peserta Didik Di Madrasah Ibtidaiyah Mambail Falah Tongas-Probolinggo. 6(1), 84-100.

Octavian, W. A. (2018). Urgensi Memahami dan Mengimplementasikan NilaiNilai Pancasila dalam Kehidupan Sehari-Hari Sebagai Sebuah Bangsa. Bhinneka Tunggal Ika, 5(2), 123-128.

Sari, L. K., \& Dewi, D. A. (2021). Peran Pancasila dalam kemelut kehidupan berbangsa dan bernegara. 04, 119-124.

Silitonga, T. B., Pertahanan, M., Pertahanan, U., \& Artikel, S. (2020). Tantangan globalisasi , peran negara, dan implikasinya terhadap aktualisasi nilai-nilai ideologi negara. 17(1), 15-28. 